\title{
Living as a diakonos of Christ and pastoral care to the narcissistically entitled person
}

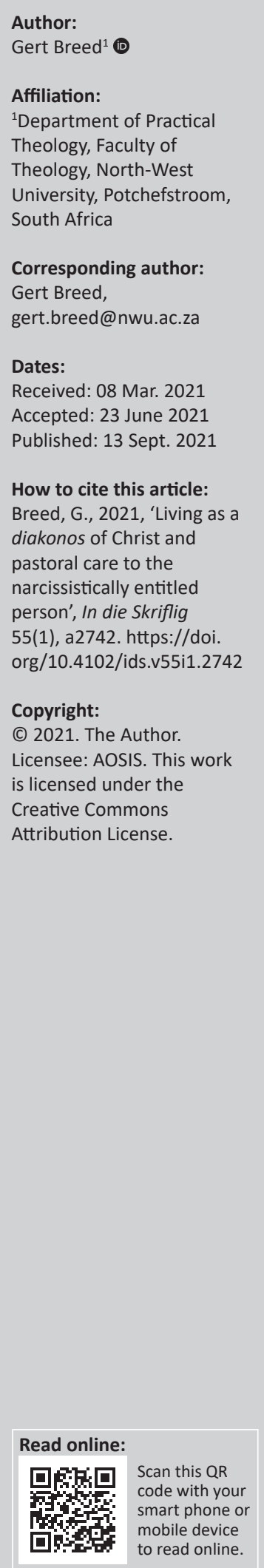

In many research documents, the current age is called the age of entitlement. Closely associated with some forms of entitlement is narcissism. When the church encounters such widespread phenomena, she should consider possibilities and ways to address those in her pastoral care. The theoretical argument of the article is that the church could pastorally care for a Christian who leads a life of narcissistic entitlement, by guiding him to lead the life of a diakonos of Christ according to the New Testament. The relationship between narcissism and entitlement is described, as well as the characteristics of narcissistically entitled persons, and how problems may develop from a narcissistically entitled attitude. A short description is then given of a pastoral process that might be used. Part of the counselling process is to bring someone in the presence of God (coram Deo) to understand what God's mercy and his prescriptions mean to him or her in his problematic situation.

Contribution: Lastly, different passages in which the diakon-words occur in the New Testament were studied and applied to the pastoral care of a narcissistically entitled person in the coram Deo-phase of pastoral care. Based on the results, it can be concluded that in the coram Deophase of the pastoral process, the pastoral care of narcissistically entitled persons may be enhanced by leading them to embrace and practise their identity as diakonos of Christ.

Keywords: narcissism; entitlement; pastoral care; pastoral counselling; church; coram Deo.

\section{Introduction ${ }^{1}$}

In many research documents, the current age is called the age of entitlement (Montanye 2016:63; Zondag \& Van Uden 2011:20). Closely associated with some forms of entitlement is narcissism, which has found international attention with reference to the previous American president being allegedly narcissistic (cf. Charnes \& Lithwick 2018). In these documents the phenomenon of entitlement and narcissism is described from various viewpoints, but the important subject of pastoral care to the narcissistically entitled person is not directly addressed. When the church encounters such widespread phenomena, she should consider possibilities and ways to address those in her pastoral care. The theoretical argument of this article is that the church ${ }^{2} \mathrm{could}$ pastorally care for a Christian who leads a life of narcissistic ${ }^{3}$ entitlement, by guiding him $^{4}$ to lead the life of a diakonos of Christ according to the New Testament. This is done by a literature study, as well as exegesis of certain New Testament passages. The focus of the article is on pastoral care to the individual who struggles with narcissistic entitlement.

South Africa has had its fair share of possible narcissistic entitlement phenomena and actions, from apartheid, corruption (Dassah 2008:43; Webb 2009:8) and state capture to the looting of businesses and banks and the FeesMustFall campaign (Judical Commission of Inquiry into Allegations of State Capture 2019). By each of these actions is assumed in some way that a specific individual or group has the right to be treated as being more special than others are, with sometimes dire consequences for other parties. The Zondo commission ${ }^{5}$ introduced South Africans and the world to a lot of seemingly narcissistic entitled individuals and companies.

1.Parts of this article were included in the inaugural address of the author (Breed 2019).

2.Church is seen as the body of Christ living and working together in koinonia and diakonia and coming together with the liturgia to worship the Triune God. Church in this article refers to congregations of Reformed background, accepting the Bible as the Word of God.

3.Narcissism can be viewed as a category (e.g. a diagnosis of Narcissistic Personality Disorder in the DSM-5; APA 2013) or a trait. In this research, the focus is on narcissism as a trait (cf. Barnett et al. 2019:20). Ackerman and Donnellan (2013) make a distinction between normal and pathological narcissism. In this research the focus is on non-pathological narcissism in relation with entitlement.

4.The masculine form is broadly used to include the feminine form.

5.The Zondo commission is a 'judicial commission of inquiry to inquire into allegations of state capture, corruption and fraud in the public sector including organs of state' under the leadership of Justice Raymond Zondo, appointed by the President of South Africa on 23 January 2018. 
The attitude of entitlement will now first be discussed, with special attention to narcissistic entitlement. Attention will be given to the narcissistically entitled person's need of help. Then pastoral care and the process of pastoral counselling ${ }^{6}$ will be described. In the third place, the meaning of the daikon-words in the New Testament will be investigated in search of an answer to the question of how the church could minister pastoral care to people with a strong sense of narcissistic entitlement. Finally, guidelines will be given to lead narcissistically entitled persons to a life as diakonos of Christ. In this way the church may contribute to a healthier community in South Africa.

The research problem can now be formulated as follows: How can the church pastorally care for a person with strong tendencies of narcissistic entitlement by leading the person towards a life as diakonos of Christ?

\section{Entitlement}

Sometimes the attitude of entitlement could closely be related to narcissism. Twenge and Campbell (2009:879) state the following: 'Entitlement, the state of mind that believes one deserves special treatment, is an important symptom of narcissism'. It is therefore necessary to reflect on narcissism to gain a deeper insight into entitlement.

Narcissism is a strong focus on the self, accompanied by a lack of empathy, a need of admiration and fantasies of omnipotence and grandeur (American Psychiatric Association [APA] 2013). Roche et al. (2013:237) describe narcissism as 'an orientation toward seeking out self-enhancement experiences from the social environment to satiate need for admiration and recognition'. More insight is gained into entitlement as a symptom of narcissism from the distinction made by Zondag (2007:86) between centrifugal and centripetal narcissism.? Centrifugal narcissism is the view of a person that he or she has influence and power over others. 'It manifests itself as the appropriation of executive skills, the ability to influence others, and the gratification derived from being the center of attention' (Zondag 2007:86). When this need is not satisfied, anger and frustration may develop. Centripetal narcissism has other people as its focus point. The person experiences himor herself as being ruled by others, being sensitive to other's opinions and easily hurt by others, always on the lookout for criticism by others, and easily embarrassed.

Zondag (2007) points out the hierarchy in the two types of narcissism, saying:

In centrifugal dependence the self dominates the other, whereas in centripetal dependence the other dominates the self. In both these two types of narcissism, the individual's own needs take

6.Pastoral counselling is seen as part of pastoral care. Pastoral care is used in this article in the sense of all care that is given by the community of believers to each other and other people, the ministry of God's grace and love in practical situations other and other people, the ministry of God's grace and love in practical situations people, leading them to understand what the grace of God and the prescriptions of the Word entails for them in the specific problem.

7.Narcissism has also been distinguished in terms of grandiose and vulnerable narcissism (Boldero, Higgins \& Hulbert 2015) with the same difference as that between centrifugal and centripetal narcissism (cf. also Besser \& Priel 2010). precedence over those of others and that fantasies of greatness prevail. (p. 87)

Zondag (2007:87) sums up the comparison by saying both types of narcissism entail the individual comparing himself to other people.

One could add a core aspect of narcissism, namely that narcissists depend on others for peace of mind and wellbeing. They have a need of confirmation of their worth, which they can only get from their relationship with other people. The reaction of other people to the narcissists' need determines their peace and joy. Grubbs, Exline and Campbell (2013:193) conclude, saying about unhealthy entitlement: 'At the core of entitlement is the belief that one deserves or is entitled to more than other people'. Narcissistically entitled persons do not only seek the satisfaction of a need but in their minds, they demand it. They are convinced that they have the right to expect their needs to be met, even at the cost of other people's wellbeing.

Knowlton and Hagopian (eds. 2013:10) recognise the reason for the expectations of the narcissistically entitled, saying, "'entitlement" arises not from an over empowerment personality, but an under empowerment and frustrated one, seeking autonomy where it may'. It can be concluded that narcissistic entitled persons are narcissists that experience under empowerment and frustration because they believe they are dependent on other people to fulfil their need of constant affirmation of their worth. The normal need for affirmation and acknowledgement does not establish narcissistic entitlement but is only established by a heightened and constant need for repeated affirmation of your own worth.

The results of a narcissistically entitled way of life are seen in different shapes as described by the following examples:

- Narcissistically entitlement encourages people to compete for strategic advantages instead of striving for success via the road of planning, hard work and sacrifice, that is, climbing the ladder of success gradually (Montanye 2016:63).

- Steele (2015:2) is of the opinion that minorities - meaning those that are weak and few in number - possibly find their identity in grievance and inferiority: 'Its seductive whisper to them was that their collective grievance was their entitlement and that protest politics was the best way to cash in on that entitlement'.

- Grubbs et al. (2013:193) say that highly entitled persons are likely to feel they do not receive what they perceive as rightfully theirs. In such circumstances, 'highly entitled individuals tend to be angry, aggressive, and demanding of those individuals around them, and they have difficulty forgiving others for perceived slights'.

Referring to the anger mentioned above, the narcissistically entitled individual's anger could be focussed on God, because God is seen as the ultimate cause of the loss of perceived honour or other entitled rights (Grubbs et al. 2013:193). 
People with centripetal narcissism and entitlement may use prayer as a means of trying to force God to help them when they feel vulnerable, powerless and lacking in self-confidence (Zondag \& Van Uden 2011:24).

Wragg (2004) describes the consequences of a narcissistic minister in the church as follows:

[T] oday's generation of shepherds are easily seduced by the lure of public recognition, wealth, power, sensuality, and personal significance. The evangelical landscape has become a wasteland of shattered trust and scattered sheep, largely due to a crop of leaders who have traded their pastoral call for personal gain. (p. 52)

In pastoral care and counselling, the church should understand certain forms of entitlement stems from narcissism, and that it sometimes can have destructive consequences. When relationships deteriorate because of the actions of a narcissistically entitled person, and either the entitled person or the people on the receiving end of entitlement seek help, the church should be willing and equipped to address this phenomenon and lead people to think and live according to the prescriptions of the Bible (Eph 4:17-32; Rm 12).

The process of pastoral counselling will now be explored.

\section{Pastoral care and counselling}

Generally, Christians leading a life of narcissistic entitlement will seek pastoral help when their ways of life cause them problems. It is also possible that people affected by somebody else's life of narcissistic entitlement, will come for pastoral help.

Firstly, it will be helpful to distinguish between pastoral care and pastoral counselling (cf. also Clinebell \& McKeever 2011:97-99). Pastoral care is the broad spectrum of the ministry of the church. Every aspect of the ministry, from the Sunday service to catechesis and child and youth care, from house visiting to small group meetings, is part of pastoral care (Collins 2011:4). Louw (2012:15) defines pastoral care as cura animarum, care of the human soul within a helping relationship. Clinebell and McKeever (2011:4, 8-9, 26) say pastoral care is a ministry of caring for individuals, families and other relationships with the objective to heal brokenness, cultivate wellness in all dimensions of live and the systems that affect a troubled person's live.

Pastoral counselling is pastoral care focussed on the individual, with the aim of addressing a personal problem cycle. Clinebell (2011:26) says pastoral counselling is a more specialised aspect of pastoral care, which implies assisting people in crisis, with the application of biblical principles. A pastor utilises the knowledge about God, humankind, sin and salvation to help people in distress, and utilising behavioural sciences as well (Asquith 2010:246).

Of course, though the emphasis is on the individual, more people could be involved in a specific situation. ${ }^{8}$

8.See O'Connor's (2003) defence of the viewpoint that there is no difference between pastoral care and counselling. See also Snodgrass (2015:1-32) for a description of the diversity of approaches to pastoral counselling.
People who accept the Bible as the authoritative source of Christianity, believe that guidelines can be found in the Bible for daily live and for reconciling, healing, reprimanding and exhortation (cf. 2 Tm 3:14-16). The purpose of both pastoral care and pastoral counselling is to lead people to discover these guidelines from the Bible. For a person who believes that God reveals himself in the Bible, studying the Bible is also coming in the presence of the triune God (Clinton \& Ohlschlager 2011:363).

All pastoral care and counselling should bring people coram Deo, that is, 'in the presence of God' (Louw 1999:55, 56, 75, $138,145)$. The Bible also says it means 'to live in the light' (1 Jn 1:7), or 'to let Christ shine on you' (Eph 5:8-14). In pastoral counselling, the question that should be answered is the following (Clinton 2009:50-51, 428): What does the revelation of the triune God mean to me in my specific problematic situation? What does God's grace mean to me and what does God's guidance in his Word mean to me?

Leading people to discover the answers to these questions and to wholeness could happen within different phases in the pastoral process. The first phase is building trust in the relationship. Especially when working with a narcissistic entitled person, it is very important that the counsellor build a close relationship with the counselee so that the counselee should not feel threatened by the counsellor. The counsellor should try to convince the counselee that he or she is there to help and not to judge.

The second phase is collecting data, when the counsellor works with the counselee to become familiar with the story (narrative) of the counselee, determining his convictions, fears, longings, et cetera. In this phase, the counsellor listens more than speaks, open questions should be utilised to encourage the counselee to open his mind. The counselee should experience the honest interest and understanding of the counsellor. The counselee could be looking for rejection, and if in any way experiencing that, could withdraw from the counselling. Reflecting the facts that the counselee is giving, is an important way to communicate that the counsellor is interested to hear more and understand. The body language of the counsellor should also communicate interest and acceptance. When making some conclusions from the narrative of the counselee, it should rather be in the form of a question, like 'did I understand you correctly that ...?'. The aim is to come together to certain conclusions and not to dictate from above.

The next phase is bringing the counselee coram Deo ('in the presence of God'), determining the meaning of God's revelation for the problem at hand. Again, this should be in the form of a Bible study, discovering together what the Word says and not in any way a one-way sermon of the counsellor to the counselee. From the Bible study the counselee may then convince himself of what God is saying to him.

Then follows the phase of establishing a new way of thinking and doing with the help of other believers 
(Pretorius 2018:204-2011). From the convictions flowing from the Bible study, the counselee could be led to a decision, and be held accountable in love to stay with the decision he made himself.

The objective of pastoral counselling is therefore never just to take away the hurt of life, or even just to alter the way somebody behaves as a solution to a specific problem. The objective will always be the growth of the Christian, that is growth in the knowledge of God, God's grace, and his prescriptions for the specific problem at hand (cf. Louw 1999:23). Clinton and Ohlschlager (2011) are of the opinion, that:

$[T]$ he overarching goal of counselling is to help people change. For counsellors who embrace a Christian perspective of counselling, the goal is to help people change in the direction of Christlikeness. (p. 363)

\section{Symington says (2018):}

$[N]$ arcissism occurs when the libido or the ego takes its own self as erotic object. This suggests that there is an alternative; this may sound obvious, but this alternative is seldom focused on clearly. If there is some other object that the ego can take rather than itself, what is it? Logically, if Narcissus can fall in love with his own reflection, the alternative is that he can fall in love with another. (n.p.)

Pastoral care works with this principal that change is possible in most cases, sometimes with the aid of medication.

In pastoral care and counselling attention is given to the basic convictions of people (Clinebell \& McKeever 2011:215). From the beginning of their lives, persons form convictions about everything they will handle in their lives. These convictions will determine the way he or she evaluates a situation, and this evaluation will determine the emotion it will create in him or her and the way he or she is going to react to the situation. In every situation, he or she will ask the question, 'What does this mean to me?' and 'How should I react?' (cf. Bingaman 2014:12, 13).

Pastoral counselling is about bringing a person's convictions about a specific problem into the light of the Word. In pastoral counselling, the counsellor and the counselee could work backwards from the problem behaviour to the emotion that the counselee experienced before the behaviour, and from the emotion backwards to the conviction that caused the problem (cf. Clinton 2009:16).

The principles of pastoral counselling set out above can now be applied to an example of a person living a life of narcissistic entitlement. A husband who expects that his needs should always get preference above the needs of his wife and children, can be taken as an example. This may be his firm conviction. When his wife gives preference to the needs of the children and he thinks she should have tended to him first, he may experience anger and get depressed or nasty. In the end, this situation may cause relational problems between him and his family, which may escalate to a break in his marriage.
When this person comes to the counsellor for help, the counsellor can mistakenly only focus on altering his problem behaviour. However, if the conviction of the person stays the same, the problem behaviour will most probably reoccur because the person still feels himself entitled to preference (eds. MacDonald, Kellemen \& Viars 2013:216). The person in the example may alter his behaviour by suppressing his anger and the urge to retaliate against his wife or manipulate her to get what he thinks he deserves. This may feed a growing frustration and a feeling of rejection or being done in emotionally. When the pressure of the frustration gets high enough, the bubble may burst, and the behavioural problem may reoccur in an exacerbated form.

Pastoral counselling could start with the behaviour that causes problems for the counselee. In the above-mentioned example, it may be the counselee's behaviour ensuing from his relational difficulties, which in turn flows from his convictions about entitlement. The counselee could be led to acknowledge that his behaviour creates problems, even if he does not think he is wrong (Louw 1999:236-241). The counselee could then be prepared to bring the behaviour that causes problems for the people in his life, to the light of God's Word. He could start by describing the behaviour that the people around him find to be a problem. The counsellor and counselee should then try to establish the emotion that the counselee experiences before he acts in a problematic way. If that has been established, the question to the counselee now would be why he feels like that in certain circumstances. Why does he feel anger when he thinks his wife puts the needs of their children before his own needs? Even if it is mostly difficult to give a precise answer to this question, it leads the counselee to think about the reasons for his emotions and behaviour. Frequently it is necessary to go back to the origin of the convictions. How did he come to believe that certain things would supply him with what he need? From here, the counselee can be led to explore the convictions that give rise to his emotions and problem behaviour (Anderson 2010:65; eds. MacDonald et al. 2013:142).

At this point, it is time to lead the counselee coram Deo [in the presence of God]. What does the Word say about his convictions? Are the convictions built on truths or untruths? It is important for the counsellor and counselee to agree about this aspect of the relevant convictions, namely whether they are built on truths or untruths (Pretorius 2018:192). It is therefore important that the counsellor establishes if the counselee is convinced whether his behaviour is appropriate or inappropriate from God's perspective.

There is, however, another important question to answer: What is the need the counselee wants to be met by his conviction? Is it a legitimate need according to the Word of God, and if it is, how does God want his children to satisfy that need (eds. MacDonald et al. 2013:115). The counsellor and counselee thus do not only work with what the counselee should do (the imperative), but also what God provides to satisfy a legitimate need (the indicative). In this way, the counselee is brought coram Deo [in the presence of God], to 
hear God's revelation about his grace and directions (cf. Powlison 2005:62, 63). The question that must be answered now, is the following: What does God want my convictions to be, and how do my current convictions compare to God's truth? The question may also be asked from another angle: What are the implications of the revelation about God the Father, God the Son and God the Holy Spirit for my convictions? Yet another way of formulating the question, is the following: How do each of the persons in the Trinity provide for my legitimate needs, and what are the implications of the triune providence for my convictions, emotions and behaviour? (cf. Anderson 2010:126; eds. MacDonald et al. 2013:216-217).

The counselee could now make a firm decision to build his emotions and behaviour on the truth of God's Word, and to discard the previous convictions that have proved to be built on untruths (Pretorius 2018:202). It could be stated in another way: He could decide to satisfy his legitimate needs with what God provides, and not with what causes problems in his life, because that is built on a lie (Anderson 2010:139).

This will be a process of repetition and conditioning, but not in a behaviouristic sense of repetition (MacArthur \& Mack 2017:9). The process can be described as follows: When the counselee experiences the trigger that leads him to the previous conviction, and he realises that he is thinking, feeling or acting in line with untruths, he has to stop (Pretorius 2018:208). He then must come consciously before God and confirm his decision not to act according to untruths anymore, but to live according to the truth. He must confirm his belief that the truth will set him free to live in freedom and with the joy of Christ in his heart. He should ask the Holy Spirit to fill him and change him in his mind, heart and behaviour. It is important to lead the counselee through the Word of God, to believe that the power of the Holy Spirit can change him to become more and more like Christ, and to bring freedom and real joy to his life (MacArthur \& Mack 2017:83-85). In this way, the untrue conviction is gradually replaced by the true conviction. Other believers could play a crucial role to bring him constantly before God, and to remind him of God's grace. They may help him to confirm his decision to satisfy his need with what God provides repeatedly, and not with what he has previously chosen (Powlison 2005:34, 35).

The more the counselee thinks, feels and acts according to the true conviction, the more it becomes a new habit that he acts out automatically. In this way, he does not only change his habits, but he himself is changed toward the image of Christ (MacArthur \& Mack 2017:198).

From this discussion, it is clear the Word of God plays an essential part in the counselling process. Without the correct identification of untruths and opposing truths from the Word, the process cannot be a success. The counselling process seems crucial in this regard, so that appropriate guidance is given in a not too dogmatic or directive way, in order that the counselee can personally experience Truth. If the counsellor is too dogmatic or directive, the person may immediately be rejected by the narcissistic counselee.

The hypothesis of the next part of the article is that the knowledge of what it comprises to be what the New Testament calls a diakonos, could help the counsellor to lead a counselee to a life away from narcissistic entitlement. If the counsellor can lead the counselee to a decision to live according to the directions and grace given to a life as diakonos of Christ, the counselee should eventually be able to break with problematic convictions, emotions and behaviour associated with narcissistic entitlement.

The focus in the next part of the article will be on the coram Deo-phase of the pastoral process, in counselling a narcissistic entitled person. In the coram Deo-phase, the Word of God is studied with the counselee who believes that the Bible can give guidelines towards freedom from a lifestyle that causes problems in the life of the counselee.

\section{The diakon words in the New Testament, and pastoral counselling of a narcissistically entitled person}

Traditionally it has been accepted that the diakon words in the New Testament carry the meaning of 'humble service', 'the work of a waiter or slave'. The research of Collins (2014) and Hentschel (2007) brought about a change in this conviction among researchers worldwide. According to the independent findings of these two authors, the words rather describe the work of 'a representative' or 'an envoy'. They also agree that the semantic context in which the words are used, should codetermine their meaning in each individual case (Breed 2017:349).

Some passages in the New Testament will now be selected to explore the central theoretical argument of this article, that the pastoral care of a person who lives a narcissistically entitled life, can be enhanced by applying the meaning of the diakon words in the New Testament in counselling. In other words, the argument is that if a person could replace the untrue convictions that form the basis of a person's narcissistically entitled life, by convictions based on the revelation of the diakon-words, it could bring about the desired change in his or her thinking, emotions and conduct. A diakonos serves (diakoneo) by doing practical service (diakonia). It is clear from different New Testament passages that every follower of Jesus is a diakonos [a servant] of Jesus.

I have made an exegetical study of various New Testament passages where the diakon-word group is found. My (Breed 2018) conclusion is:

When the different semantic possibilities in which the diókovword group occurs in the sections investigated are compared to each other, it is clear that different authors use the word with concurring semantic possibilities. (p. 230) 
In order to identify the different concepts (themes) found in the Siókov- word group, I (Breed 2018:230-239) combined the sections in which the same semantic possibility of the diakonwords is actualised by the author of the passage. From these concepts, two will now be discussed. The question to be answered from the discussion of the two concepts, is if and how the pastoral care of a narcissistically entitled person may be enhanced by leading him to life as a diakonos of Christ according to the New Testament.

\section{A diakonos is called and appointed by God}

In the Gospels, Jesus is quoted many times using the word ergomai [to come] to describe the purpose of his life on earth. In the Gospel of Mark (10:45) and the Gospel of Matthew (20:28), Jesus is quoted as saying that he did not come (ergomai) to be served (diakoneo) but to serve, using the diakon words (cf. Breed 2017:249-260). From these verses, it is evident that the writers of these Gospels were convinced that Jesus was sent to serve (cf. Santos 2003:96).

According to the Gospel of John, Jesus said that he was speaking only the words of his Father and doing only the deeds of the Father (Jn 14:10, 24). In his mind and service, Jesus was the representative of the Father (Breed 2015:1). In the Gospel of John, the diakon words are also used to indicate the task of Jesus' followers as representatives of the Father and the Son (Van der Watt 2000:108). The work of the Holy Spirit is indicated when John says he is the one who will remind the followers of Jesus of the words of Jesus. The writer of the Gospel of John, in chapter 12, structures verses 21-27 (see Table 1) in such a way that he makes it clear to his readers that Jesus indicated that his followers will take over his task after his resurrection and ascension. The passage in John 12:23-28 is introduced by verse 20-22 which relates a request of some Greeks to speak to Jesus. Verse 23-28 describes Jesus' reaction to their request. Jesus' description of his hour of glorification (suffering) is related in verse 23 and 24; while verses 27 and 28 describe Jesus' reaction to the hour. Verses 25 and 26 indicate what this hour means to Jesus' followers (cf. Breed 2014b:3; Neyrey 2007:215). John encloses the description of the meaning that the hour has for Jesus' followers with what the hour means to Jesus and his reaction to it.

\begin{tabular}{ll} 
TABLE 1: Structure of John 12:21-27. \\
\hline Initiating cause or trigger & $\begin{array}{l}\text { Verses 20-22: The Greeks' request - they } \\
\text { wanted to speak to Jesus }\end{array}$ \\
\hline $\begin{array}{l}\text { A1: Jesus' interpretation of the meaning } \\
\text { of their request }\end{array}$ & $\begin{array}{l}\text { Verse 23: Jesus' answer that the hour of } \\
\text { his glorification had come }\end{array}$ \\
A1: The meaning of the hour to Jesus & $\begin{array}{l}\text { Verse 24: Jesus' explanation of the 'hour' } \\
\text { by the image of the grain of wheat that } \\
\text { had to die }\end{array}$ \\
$\begin{array}{ll}\text { B: The meaning of the hour to his } & \begin{array}{l}\text { Verse 25: Jesus' application of the } \\
\text { principle of life through death to his } \\
\text { followers }\end{array} \\
\text { B: What it encompasses to follow Jesus } & \begin{array}{l}\text { Verse 26: Jesus' explanation of what it } \\
\text { means to serve Him }\end{array} \\
\text { as his diakonos } & \begin{array}{l}\text { Verse 27: Jesus expressing his anxiety } \\
\text { about his hour of suffering and death, his } \\
\text { inner conflict and his conclusion }\end{array} \\
\text { A2: Jesus considering his task } & \begin{array}{l}\text { Verse 28: Jesus not wanting to sidestep } \\
\text { the hour, but wishing to glorify the Father }\end{array} \\
\text { A2: Jesus' decision } & \end{array}$ \\
\hline
\end{tabular}

Verse 26 links the task of Jesus with that of his followers: 'If anyone serves me, he must follow me; and where I am, there will my servant be also. If anyone serves me, the Father will honour him'.

Jesus speaks to every one of his followers ('̇ò̀ $\dot{\varepsilon} \mu o i ́)$ and says serving (diakoneo) him requires one to follow him (Lee 2010:118). In this context, it means following him in his obedience to the Father, even unto death. In the last two parts of the sentence, the consequences of serving by following are described. The first consequence, 'to be where Jesus is', might be positive or negative. Positively it could be interpreted that the followers of Jesus will be in the same relationship to the Father as Jesus, being one with the Father. In the light of the last part of the sentence, it should probably be interpreted positively, meaning to be honoured by the Father, like Jesus. Negatively it could mean that they will also suffer like Jesus. However, Jesus calls his suffering the 'time of his glorification' (Jn 12:23), because He will conquer evil on the cross. To follow Jesus in his obedience to the Father means glorification, even if you must suffer, because victory is attained through obedient suffering (cf. Anderson 1999:42; Breed 2014a:4; Van der Watt 2008:94).

Looking at the deliberate structure of John 12:20-28, it might be deduced that the author is leading his readers towards a definite decision. Jesus is presented in his evaluation of the hour and the demands of the hour, his struggle with the demands and then his clear decision to adhere to those demands. The structure calls the reader to be part of this hour and to also take a definite decision to adhere to the demands of the hour as diakonos of Jesus.

In the letters ascribed to Paul and Peter, the daikon-words also indicate the diakonos as representative of God. Paul uses the diakon-words to describe his own calling (Eph 3) and that of his co-workers (Breed 2014b:7). Peter uses the word oikonomos [steward] to describe the way the believers should use their gifts to serve (diakoneo) one another by the grace of God. The oikonomos [steward] represented the owner in the household, handled his affairs, cared for the servants and oversaw the whole management of the household (Louw \& Nida 1996:476). Both Paul and Peter see a diakonos of Christ as his representative and envoy.

\section{Application to the pastoral counselling of a narcissistically entitled person}

Narcissistically entitled persons represent themselves, always trying to appropriate the attention, honour and opportunities they think they deserve. In their minds, however, they may care and even fight for themselves in a way that always makes them feel in need of what others should give them.

In the counselling process, the counselee could be led to understand what it means to follow Jesus as a representative of Jesus and the Father and to trust the Father to attend to his or her need of honour and victory. He or she should trust Jesus, that when they relinquish their own needs, they 
will receive true life from the Father, that is, all he needs to live in peace and joy. The counselee is thus led to be a diakonos of Christ, and to transfer the responsibility of caring for his or her needs to God, so that the focus of their lives can shift to serving Jesus and others (cf. Louw 2015:533).

The counselee is also led, in the last place, to take a definite decision to be ultimately accountable to God and not to people. The narcissistically entitled person is in a certain sense a beggar in his mind, begging for appreciation and attention all the time. A diakonos of Christ receives all he or she needs from God, and therefore they can live without the gifts of human beings. The love and appreciation of other people is wonderful to them, but although it may be hard, they can exist without it. They can echo Psalm 23, saying, 'The Lord is my shepherd, I shall not want'.

Pastoral care to the narcissistically entitled person therefore focuses on two aspects that should be changed. In the first place, the counselee is led to embrace the care and honour that come from God, which replaces his dependency on other people. In the second place, the counselee is led to understand and embrace his or her new calling to be a representative of the Father and the Son through the work of the Holy Spirit.

\section{The diakonos of Jesus delights in the wellbeing of other people}

Like Mark 10, Matthew 20:17-19 relates the incident in which Jesus (again) announced his coming suffering, crucifixion, death and resurrection. Directly after his announcement, the mother of James and John asked Jesus if her sons could sit in the privileged places on his right and left hand in his coming kingdom (Mt 20:20-21). Some writers have named James and John 'sons of entitlement' because of the request. Jesus then pointed out that they did not know what they were requesting and then asked if they could drink the cup that he was going to drink and be baptised with his baptism. The sons' positive reply shows that they indeed did not understand Jesus' words. With this question, he taught them (and Matthew his readers) that the way to greatness in the kingdom is obtained through suffering. Jesus then told them that they would indeed suffer for his sake (drink his cup), but that only the Father would decide on who would sit in the privileged places. The other disciples were angry with the two sons, who wanted to take advantage of the situation and claim the best places.

Jesus then taught the disciples in more detail about the way to greatness and the longing to be the first. You should relinquish furthering your own case and not care about how other people are dealt with. Jesus' words following here in Matthew are the same as Jesus' words in Mark 10:42-45, namely that those who want to be first, should be everyone's diakonos and those who want to be great, should be everyone's doulos. Jesus motivated his teaching by referring to his own lifestyle: because the Son of man did not come to be served, but to serve.
Breed (2017:85) indicates that the meaning of this teaching in Matthew cannot be fully understood if the immediate context in Matthew 19 and 20 is not considered. In Matthew 19:16-26, Jesus' conversation with a rich man is related. From the conversation, it becomes clear that the man relied on his own works to inherit the kingdom of God. He felt himself entitled to enter the kingdom of God because he kept the law of God from childhood.

Jesus then asked him to give everything away and follow him. What Jesus asked from him, is to abandon his love for money, belongings and honour in exchange for the love of the kingdom of God. The man went away because of his love for his belongings and everything that came with it.

In reaction to this incident, Peter asked about the disciples' reward, because they had left everything and followed Jesus (Mt 19:27). With this question, Peter revealed the same mindset as the rich man, as he thought about (feeling entitled to) being rewarded for what he had done.

Jesus replied that their reward would indeed be great, but he added that 'many who are first will be last, and the last first' (Mt 19:30). Jesus then told them a parable to clarify his teaching (Mt 20:1-15) and closed the parable with the same saying slightly altered: 'So the last will be first, and the first last' (Mt 20:16).

Matthew follows Mark 10 by discussing the same topics in Matthew 19:1-29, and he does so again from Matthew 20:17, but Matthew 20:1-16 is unique to Matthew. It can thus be assumed that he deliberately placed this parable between Peter's question and Jesus' announcement of his imminent suffering. The question of the two brothers and Jesus' teaching about the way his disciples should act if they wanted to be first and become great (Mt 20:17-28). If this structure is accepted, the meaning of the parable is important for understanding Jesus' teaching about the diakon-words in Matthew 20:26-28.

The parable is also linked with the incident of the rich man and Peter's question about their reward by the word, 'because' ( $\gamma \alpha \dot{\rho} \rho)$, with which Jesus started the parable (Mt 20:1). He then indicated that he told the parable to clarify the way it is in the kingdom of heaven:

Matthew 19:29-20:1: And everyone who has left houses or brothers or sisters or father or mother or children or lands, for my name's sake, will receive a hundredfold and will inherit eternal life. But many who are first will be last, and the last first. For the kingdom of heaven is like a master of a house who went out early in the morning to hire laborers for his vineyard ... (ESV)

The parable tells about the owner of a harvest who did not have enough labourers and went out repeatedly (five times) on one day to get more and more labourers, even up to the last hour of the working day. For the reader of the whole of Matthew, the parable brings to mind the saying of Jesus recorded in Matthew 9:37-38: 'The harvest is plentiful, but 
the laborers are few; therefore pray earnestly to the Lord of the harvest to send out laborers into his harvest' (ESV). This was said by Jesus because, according to Matthew 9:36, 'When he saw the crowds, he had compassion for them, because they were harassed and helpless, like sheep without a shepherd' (ESV).

Read in the light of Matthew 9:36-38, the parable points to God's compassion on those who do not have Jesus as their shepherd, and to God's way of bringing them to Jesus and into his kingdom. God's way is to hire more and more labourers to bring in the harvest. The main point of the parable is, however, about who will be first and who will be last, because that is how the parable starts and ends. When the parable is read closely, however, it becomes clear that it also deals with the attitude of the labourers about the reward they would get for their work, and whether they understand the way of the kingdom of God.

The owner hired labourers early in the morning and made an agreement with them about their reward. At different hours of the day, he then hired more and more labourers without mentioning any precise reward.

When the working day was over, he told the paymaster to begin with the labourers that were hired in the last hour of the day, and said that they should be paid the same amount as he had agreed upon with those who were hired first. By making payments in this way, it is indicated that those who were hired first, were meant to take note of the fact that all the labourers received the same payment, irrespective of how long they had worked. When those who were hired first were paid, they grumbled about the fact that they received the same as those who were hired last. The owner stood by his agreement with them, saying that he did them no wrong because he paid them as they had agreed.

Matthew (and Jesus) also told the events in this order, to draw the attention of his readers to the attitude of labourers who were hired first. Why could those that were hired first not be happy that the owner had mercy on those who were hired last, and gave them enough money for one day's survival? The landowner's question to the labourers was the following: 'Or is your eye evil because I am good?' In the New Testament, the expression 'evil eye' stands for stinginess and begrudging other people's good fortune (Judge 2011:502-504). The attitude of the workers is contrasted with the goodness of the owner; his goodness agitated them. Breed (2017:266) formulates it like this: 'The people who were hired first thought only about themselves and they could not rejoice in the grace that those who were hired last received from the landowner'.

Jesus was addressing the attitude of the disciples (and Matthew that of his readers). They were the labourers that were hired first. Peter's attitude when he enquired about their reward, John and James' attitude when they requested the best places in the kingdom and even the other disciples' anger towards them for requesting this privilege, were the same as that of the labourers hired first. Everyone seems to be focussed on their own benefit and struggling to consider the benefit of the others. They all had something of an attitude of entitlement. Matthew deliberately structured his gospel in this way as to challenge his readers with the same challenge as he relates how Jesus dealt with his disciples.

A key to understanding the parable is found in the significant words of the owner to the labourers hired later in the day: 'You go into the vineyard too, and whatever is right I will give you' (Mt 20:4, 7). They had to work, trusting the owner to give them what is right. When Jesus said at the beginning and end of the parable that the first would be last and the last first, it is not fully clear what it would entail, but the following is clear according to Breed (2017):

Jesus thus illustrated the total divergence of the way things work in the kingdom of heaven ... Jesus came to change existing perspectives on many things, also the way the poor and the vulnerable should be treated and how one should look at the good fortune of others. (p. 267)

The way of the kingdom (first last and last first) concerning the reward for the workers in the kingdom, is not to be fully explained in this life, but it is certain that God will do what is right to his workers. Their eyes do not need to be evil because they begrudge other people's good fortune. They are cared for, because God will do right to them in every situation. The workers in the kingdom could rest in this certainty. From this space of certainty and rest, they will be able to rejoice in the grace other people receive from God.

From these arguments, it can be deduced that in the parable, Jesus addressed the attitude of his disciples, as shown by Peter with his request about their reward and James and John's request for privileged places in the kingdom. This is the same attitude as that of the rulers of the Gentiles (Mt 20:25). This was also the attitude of the workers who were hired first according to the parable, an attitude of entitlement. In contrast to this attitude, Jesus explained to them his own attitude, namely that He lived his life on earth not to be served but to serve (Mt 20:28). For the disciples this meant that if any one of them wanted to be first, he had to become the diakonos and slave of other people (cf. Breed 2017:254, 255). Jesus is leading them (and Matthew his readers) to change their viewpoint and attitude towards that of a diakonos following Christ in his attitude.

\section{Application to the pastoral counselling of a narcissistically entitled person}

In pastoral counselling, this passage could be studied with the counselee, helping him to understand the way of the kingdom of God. Helping him to decide to change his ways according to the Word of God.

The narcissistically entitled people's focus in life is on him- or herself and their own needs. This could blind them for the needs of other people. Instead of being glad when other 
people receive some privileges, they envy those people and feel robbed, because they did not receive the same. They must be led to embrace the indicative of a God who is good and who will do right to them. They must be led in the counselling process to understand God's compassion for people in need. They then must work hard to make this compassion their own, asking the Holy Spirit to work compassion in their hearts, and asking accountability partners to remind them of leading a life of compassion when they act again from a perspective of narcissistic entitlement. They must learn to rejoice in the good fortune of other people, even if they are, according to the prevailing norms of society, also entitled to privileges, but are overlooked. Doing this, each one will increasingly live as a diakonos of Christ, finding freedom from narcissistic entitlement.

\section{Conclusion}

Narcissistic entitlement may cause relational problems in a person's life and bring him or her to a point where they seek help from a pastoral counsellor.

Part of the counselling process is to bring someone in the presence of God (coram Deo), to understand what God's mercy and his prescriptions mean to him or her in his problematic situation.

Two passages where the diakon-words occur in the New Testament, were studied and applied to the pastoral care of a narcissistically entitled person in the coram Deo-phase of pastoral care. Based on the results, it may be concluded that in the coram Deo-phase of the pastoral process, the pastoral care of the narcissistically entitled person could be enhanced by leading him or her to embrace and practise his identity as diakonos of Christ. By living as diakonos of Christ, he or she may be liberated from the attitude of entitlement.

\section{Acknowledgements Competing interests}

The author has declared that no competing interest exist.

\section{Author's contributions}

G.B. declares that he is the sole author of this research article.

\section{Ethical considerations}

This article followed all ethical standards for research without direct contact with human or animal subjects.

\section{Funding information}

The author received no financial support for the research, authorship, and/or publication of this article.

\section{Data availability}

Data sharing is not applicable to this article as no new data were created or analysed in this study.

\section{Disclaimer}

The views and opinions expressed in this article are those of the author and do not necessarily reflect the official policy or position of the NWU.

\section{References}

Ackerman, R.A. \& Donnellan, M.B., 2013, 'Evaluating self-report measures of narcissistic entitlement', Journal of Psychopathology and Behavioral Assessment 35(4), 460-474. https://doi.org/10.1007/s10862-013-9352-7

American Psychiatric Association (APA), 2013, Diagnostic and statistical manual of mental disorders: DSM-5, American Psychiatric Association, Washington, DC.

Anderson, P.N., 1999, 'The having-sent-me Father: Aspects of agency, encounter, and irony in the Johannine Father-Son relationship', Semeia 85, 42.

Anderson, R.S., 2010, Christians who counsel: The vocation of wholistic therapy, Wipf \& Stock, Eugene.

Asquith, G.H., 2010, The concise dictionary of pastoral care and counselling, Abingdon Press, Nashville, TN.

Barnett, M.D., Maciel, I.V. \& King M.A., 2019, 'Sandbagging and the self: Does Narcissism explain the relationship between sandbagging and self-esteem?', Journal of Individual Differences 40(1), 20-25, https://doi.org/10.1027/16140001/a000272

Besser, A. \& Priel, B., 2010, 'Grandiose narcissism versus vulnerable narcissism in threatening situations: Emotional reactions to achievement failure and interpersonal rejection', Journal of Social and Clinical Psychology 29(8), 874-902. https://doi.org/10.1521/jscp.2010.29.8.874

Bingaman, K.A., 2014, The power of neuroplasticity for pastoral and spiritual care, Lexington Books, ProQuest Ebook Central, viewed 14 January 2019, from https:// ebookcentral.proquest.com/auth/lib/northwu-ebooks/login.action?returnURL=h ttps $\% 3 \mathrm{~A} \% 2 \mathrm{~F} \% 2 \mathrm{Feb}$ ookcentral.proquest.com $\% 2 \mathrm{Flib} \% 2 \mathrm{Fnorthwu}$ ebooks\%2Fdetail.action\%3FdocID\%3D1676473

Boldero, J., Higgins, E. \& Hulbert, C., 2015, 'Self-regulatory and narcissistic grandiosity and vulnerability: Common and discriminant relations', Personality and Individual Differences 76, 171-176. https://doi.org/10.1016/j.paid.2014.12.019

Breed, G., 2014a, 'The meaning of the diakon word group in John 12:26 applied to the ministry in congregations', Verbum et Ecclesia 35(1), Art. \#844, 8 pages. https:// doi.org/10.4102/ve.v35i1.844

Breed, G., 2014b, "n Kritiese blik op missio Dei in die lig van Efesiërs', In die Skriflig 48(2), Art. \#1707, 10 pages. https://doi.org/10.4102/ids.v48i2.1707

Breed, G., 2015, 'Finding guidelines on social change in the two-tiered narrative and diakonia in the Gospel of John', HTS Theological Studies 71(2), Art. \#2666, 8 pages. https://doi.org/10.4102/hts.v71i2.2666

Breed, G., 2017, 'A social movement against corruption in the footsteps of Jesus' diakonia according to Matthew', in F. Kruger \& B. de Klerk (eds.), Corruption in South Africa's liberal democratic context: Equipping Christian leaders and communities for their role in countering corruption, pp. 247-279, AOSIS, Durbanville.

Breed, G., 2018, 'The diakon-word group in the New Testament and congregational ministry', PhD thesis, Radboud University, Nijmegen.

Breed, G., 2019, Living as a diakonos of Christ and pastoral care to the narcissistically entitled person, North West University, viewed 20 April 2021, from https://repository.nwu.ac.za/bitstream/handle/10394/31992/Breed_G.pdf? sequence $=1$ \&isAllowed $=\mathrm{y}$.

Charnes, L. \& Lithwick, D., 2018, 'Trump's caught the press in his narcissistic web, The president's pathologies entrap us all, but the press needs to figure out a way to escape the loop', viewed 24 January 2019, from https://slate.com/news-andpolitics/2018/11/trump-press-narcissism-psychology.html

Clinebell, H. \& McKeever, B.C., 2011, Basic types of pastoral care \& counseling, Abingdon Press, Nashville, TN.

Clinebell, H.J., 2011, Basic types of pastoral care \& counseling: Resources for the ministry of healing and growth, Abingdon Press, Nashville, TN.

Clinton, T., 2009, Caring for people God's way: Personal and emotional issues, addictions, grief, and trauma, Thomas Nelson, Nasville, TN.

Clinton, T.E. \& Ohlschlager, G.W., 2011, Competent Christian counseling, vol. 1: Foundations and practice of compassionate soul care, WaterBrook Press, Colorado Springs, CO.

Collins, G., 2011, A-Z van Berading, Cornelis Struik House, Kaapstad.

Collins, J.N., 2014, Diakonia studies: Critical issues in ministry, Oxford University Press, Oxford.

Dassah, M.O., 2008, 'Is there a hole in the bucket? Identifying drivers of public sector corruption: Effects and instituting effective combative measures', Journal of Public Administration 43(special issue 3), 37-62.

Grubbs, J.B., Exline, J.J. \& Campbell, K., 2013, 'I deserve better and God knows it! Psychological entitlement as a robust predictor of anger at God', Psychology of Religion and Spirituality 5(3), 192-200. https://doi.org/10.1037/a0032119

Hentschel, A., 2007, Diakonia im Neuen Testament: Studien zur Semantik unter besonderer Berücksichtigung der Rolle von Frauen, Mohr Siebeck, Tubingen.

Judge, P., 2011, 'Or is your eye evil because I am good? (Mt 20, 15): What kind of justice is this?', in D. Senior (ed.), The Gospel of Matthew at the crossroads of early Christianity, pp. 499-510, Peeters, Leuven. 
Judical Commission of Inquiry into Allegations of State Capture, 2019, Corruption and fraud in the public sector including organs of state, viewed 19 July 2018, from https://www.sastatecapture.org.za

Knowlton, C.D.S. \& Hagopian, K.J. (eds.), 2013, From entitlement to engagement: Affirming students' egos in the millennial higher classroom, Wiley, San Francisco, CA.

Lee, D., 2010, 'The Gospel of John and the five senses', Journal of Biblical Literature 129(1), 115-127. https://doi.org/10.2307/27821008

Louw, D.J., 1999, A mature faith, Peeters, Louvian.

Louw, D.J., 2012, Network of the human soul: On identity, dignity, maturity and life skills, Sun Media, Stellenbosch.

Louw, D.J., 2015, Wholeness in hope care, LIT Verlag, Zürich.

Louw, J.P. \& Nida, E.A., 1996, Greek-English lexicon of the New Testament: Based on semantic domains, electronic edn. of the 2 nd edn., vol. 1, United Bible Societies, New York, NY.

MacArthur, J.F. \& Mack, W.A., 2017, Counseling: How to counsel biblically, Thomas Nelson, Nashville, TN.

MacDonald, J., Kellemen, B. \&Viars, S. (eds.), 2013, Christ-centered biblical counseling: Changing lives with God's changeless truth, Harvest House Publishers, Eugene.

Montanye, J.A., 2016, 'Grievance and shame in the modern age of entitlement', Essays in the Philosophy of Humanism 24(1), 58-85, https://doi.org/10.1558/eph.31168

Neyrey, J.H., 2007, 'The Gospel of John', in B. Witherington (ed.), The new Cambridge Bible Commentary, n.p., Cambridge University Press, New York, NY.

O'Connor, T.S., 2003, 'Pastoral counseling and pastoral care: Is there a difference?', The Journal of Pastoral Care \& Counseling 57(1-4), 3-14. https://doi. org/10.1177/154230500305700102

Powlison, D., 2005, Speaking truth in love: Counsel in community, New Growth Press, Greensboro, NC.

Pretorius, R., 2018, 'Pastoral care and counselling of families with deaf children: A practical theological model', PhD thesis, North-West University, Potchefstroom.
Roche, M.J., Pincus, A.L., Likowitsky, M.R., Ménard, K.S. \& Conroy, D.E., 2013, 'An integrative approach to the assessment of narcissism', Journal of Personality integrative approach to the assessment of narcissism', Journal of Persona
Assessment 95(3), 237-248. https://doi.org/10.1080/00223891.2013.770400

Santos, N., 2003, Slave of all: The paradox of authority and servanthood in the Gospel of Mark, Sheffield Academic Press, Sheffield.

Snodgrass, J.L., 2015, 'Pastoral counseling: A discipline of unity amid diversity', in E.A. Maynard \& J.L. Snodgrass (eds.), Understanding pastoral counseling, Springe Publishing Company, ProQuest Ebook Central, created from northwu-ebooks, viewed 14 January 2019, from http://ebookcentral.proquest.com/lib/northwuebooks/detail.action?docID $=2166668$

Steele, S., 2015, Shame: How America's past sins have polarized our country, Basic Books, New York, NY

Symington, N., 2018, Narcissism: A new theory, Routledge, Abingdon.

Twenge, J.M. \& Campbell, W.K., 2009, The narcissism epidemic: Living in the age of entitlement, Free Press, New York, NY.

Van der Watt, J., 2008, 'Johannine style: Some initial remarks on the functional use of repetition in the Gospel according to John', In die Skriflig 42(1), 91. https://doi. org/10.4102/ids.v42i1.258

Van der Watt, J.G., 2000, Family of the King: Dynamics of metaphor in the Gospel according to John, Brill, Leiden.

Webb, W., 2009, 'Prevention is better than cure: Promoting public service integrity', SA Crime Quarterly 27(3), 7-13.

Wragg, J., 2004, 'Diotrephes: The dangerous lure of power and praise', Journal of Modern Ministry 1(2), 51.

Zondag, H.J., 2007, 'Unconditional giving and unconditional taking: Empathy and narcissism among pastors', Journal of Pastoral Care \& Counseling 61(2-2), 85-87. https://doi.org/10.1177/154230500706100109

Zondag, H.J. \& Van Uden, M.H.F., 2011, “"Still knockin” on heaven's door: Narcissism and prayer', Journal of Empirical Theology 24(1), 19-35. https://doi.org/10.1163/ $157092511 \times 571150$ 